Tous ceux qui s'intéressaient à la traite des noirs connaissaient les débouchés dans l'Océan et les criques en allant vers l'ouest, dans la direction de Lagos où les transbordements avaient lieu. Un nommé Riley, qui a fait naufrage en 18 I 5 , et qui a été vendu comme esclave dans le Maroc espagnol, apprit de son maître qu'il avait visité un peuple habitant un endroit très loin vers le sud, dont le toi s'occupait, sur une échelle considérable, du trafic des esclaves vers la mer et où l'on y arrivait après un voyage d'environ trois mois, au sud et à l'ouest de son pays.

A Koumassi, en 1820 , Bowdich a reçu de deux Maures, des descriptions séparées du cours du fleuve plus près du delta. Ces Maures lui ont dressé une liste des localités situées sur ses rives. Bien que leurs informations fussent presque identiques Bowdich ne les a pas utilisées pour sa carte d'Afrique. Dupuis, qui était à Koumassi avec Bowdich, est arrivé à persuader un mallam mahométan de faire une description du fleuve d'après ses propres connaissances, récit qui a été confirmé par d'autres Arabes. Dupuis a été informé qu'il était possible de voyager de Bénin à Tombouctou entièrement par eau. Malgré cela, il indique sur sa carte que le Niger est un affluent du Nil.

Aucun de ces témoignages arabes n'a été accepté par les Européens comme étant entièrement véridique jusqu'au moment où ils ont eux-mêmes établi leur authenticité.

\title{
Margaret Wrong Medal
}

\section{Regulations i95s}

r. The MARGARET WRONG MEDAL is offered in 1955 for a published work of outstanding literary merit by an African whose home is in West Africa, including French West and French Equatorial Africa, Liberia, Gambia, Sierra Leone, Gold Coast, and Nigeria.

2. Only original work written in an African language and published between I January I95 2 and 3 I December 1955 will be considered.

3. Except for entries comprising collections of original verse, books of less than 25,000 words will not normally be considered.

4. No author may submit mote than one book, two copies of which should be delivered after 3 I December 1955 and before 28 February 1956 to:

Le Directeur de l'Institut Français d'Afrique Noire, Dakar, A.O.F.

(For entries from French West Africa.)

The Secretary, Protectorate Literature Bureau,

Box 28, Bo, Sierra Leone. (For entries from Liberia, Gambia, and Sierra Leone.)

The Secretary, Institute of Education, University College of the Gold Coast, Accra, Gold Coast. (For entries from the Gold Coast (including Togoland).)

The Federal Adviser on Education,

The Secretariat,

Lagos, Nigeria. $\quad$ (For entries from Nigeria (including the Cameroons).)

5. Entries should be clearly marked Margaret Wrong Medal.

Note: After examination by judges competent in the language in which each book is written, any book which is recommended will be forwarded to London, where the award will be made by a special body of assessors. The decision of the assessors will be final.

NO AWARD WILL BE MADE UNLESS A WORK IS PRESENTED WHICH IS OF OUTSTANDING MERIT AS LITERATURE. 